\title{
Effect of ground flaxseed on the carcass characteristics of Karadi male lambs
}

\author{
C.A. Omar, A.N. Yousif*, M.K. Arif and H.G. Zahir \\ Animal Sciences Department, College of Agricultural Sciences, Sulaimani University, Sulaymaniyah, Iraq \\ *e-mail: awat.usif@univsul.edu.iq
}

(Received April 22, 2018; Accepted July 31, 2018)

\begin{abstract}
To investigate the effect of dietary supplementation of Ground Flaxseed (GF) on performance and carcass characteristics of Karadi male lambs. Flaxseed was used in feeding period that lasted for 90 days using twelve ram Karadi lambs, at 6 months old, which divided into 3 equal groups ( $4 \mathrm{rams} /$ group). The lambs were randomly allocated into three treatments to receive either control ration (no Ground flaxseed), or ration containing 4\% Ground Flaxseed (T1), or diet containing 8\% Ground Flaxseed (T2). All the lambs were received an equal daily allowance of concentrate ration (3\% of the body weight). At the end of feeding trial ( 8 weeks), all the lambs were slaughtered. They were weighed immediately before slaughter to provide slaughter body weight (SBW). Immediately after skinning, evisceration was carried out and the carcass components were weighted. Then several quantity characteristics for carcasses were studied, which include: hot carcass weight (HCW), dressing percentage, thickness of subcutaneous fat, rib eye area, partition and cutting of Carcass. Data were analyzed using XL Stat. The results showed that GF has no significant effect on live body weight, hot carcass weight, and dressing percentage \%, it also has no significant differences on some carcass cuts for example: leg, shoulder, loin, rack, fore shank and neck. On the other hand, GF supplementation caused a significant $(\mathrm{P}<0.01)$ decrease in Sub-fat thickness which was $3.695 \pm 0.629$ and $2.375 \pm 0.191$ in T1 and T2 respectively in comparison to control group $5.015 \pm 0.049 \mathrm{~mm}$. Rib eye area increased significantly $(\mathrm{P}<0.05)$ in $\mathrm{T} 1$ and $\mathrm{T} 2$ treatments $(12.035 \pm 0.205$ and $14.145 \pm 0.955$ respectively) compared to control $(10.005$ $\left.\pm 1.039 \mathrm{~cm}^{2}\right)$. Some of the carcass cuts, Breast and Flank, decreased significantly $(\mathrm{P}<0.05)$ in $\mathrm{T} 2$ compared to T1 and Control. In conclusion, GF supplementation significantly decrease breast and flank cuts, while rib eye area significantly increased. However, the decrease in fat thickness may be reflecting the decrease in fat percentages in the carcass that indicates the effect of GF in improvement of carcass traits.
\end{abstract}

Keywords: Ground Flaxseed, Karadi Ram Lambs, Hot Carcass Weight, Dressing Percentage, Rib Eye Area Available online at http://www.vetmedmosul.com

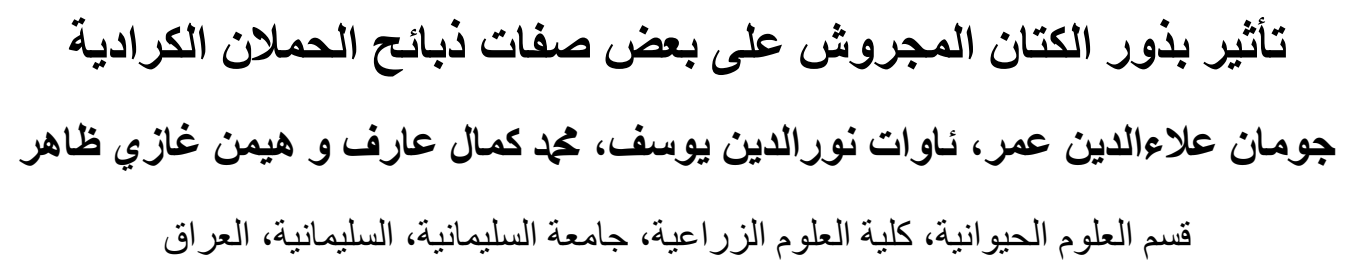

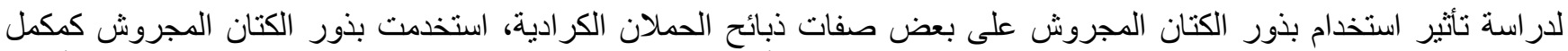

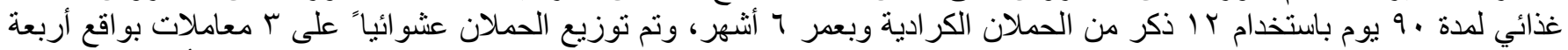

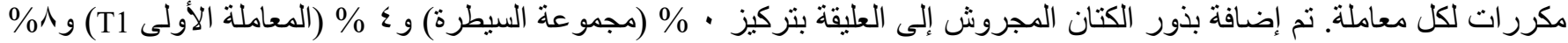

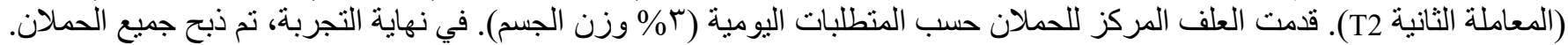

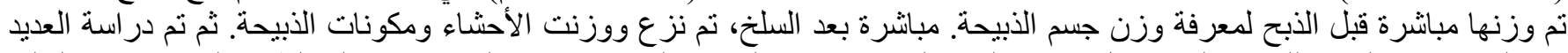

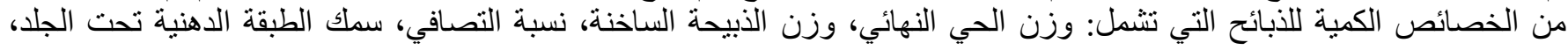




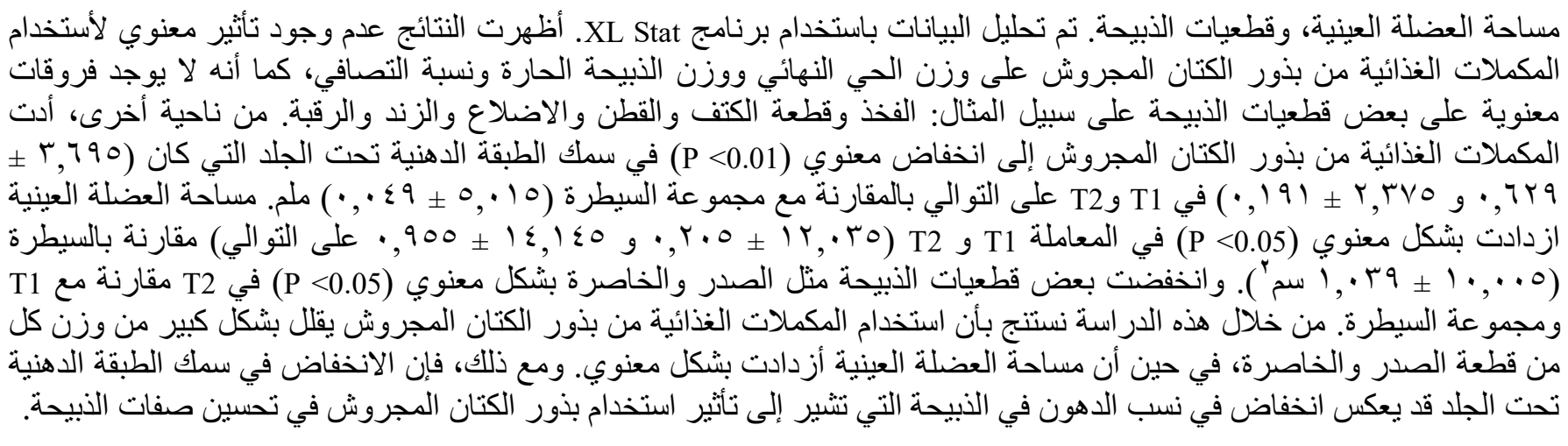

\section{Introduction}

Meat is a food that contains most of the nutrients necessary for livability, growth and physiological functions, it plays very important roles in the human nutrition by contributing high quality proteins, essential minerals and trace elements and a range of $\mathrm{B}$ vitamins in bio available forms (1). However red meat contains high biological value protein and important micronutrients that are needed for good health throughout life. It also contains a range of fats, including essential omega-3 polyunsaturated fats. There has been an increased interest in recent years in ways to manipulate the fatty acid composition of meat. This is because meat is seen to be a major source of fatten the diet and especially of saturated fatty acids, which have been implicated in diseases associated with modern life, especially in developed countries. For this reason, ways to improve the polyunsaturated fatty acid: saturated fatty acid (P:S) ratio during meat production are required (2). In light of many studies conducted mainly with beef cattle, its essential to the efficient use of vegetable oils by ruminants is prevention of polyunsaturated fatty acids (PUF) in feeds from biodegradation in the rumen. The simplest and cheapest way of achieving this is to feed whole oilseeds (3). Many scholars think this requires supplementing the feeds with antioxidants, vitamin $\mathrm{E}$ being the most efficient and natural one (4). Brown-seeded flax, which is rich in alpha linolenic acid (ALA), an omega-3 fatty acid, is the most common flax grown in Canada. The terms "flaxseed" and "linseed" are often used interchangeably, although North Americans use "flaxseed" to describe flax when it is eaten by humans and "linseed" to describe flax when it is used for industrial purposes, such as linoleum flooring. In Europe, the term "flaxseed" describes the varieties grown for making linen (5). Flax is rich in oil, protein and dietary fiber. An analysis of brown Canadian flax consists of averaged $41 \%$ oil, $20 \%$ protein, $28 \%$ total dietary fiber, $7.7 \%$ moisture and $3.4 \%$ ash (6). The chemical composition varies considerably among varieties and also depends on the environmental conditions in which the plant is grown
$(7,8)$. Flaxseed can be effectively used in feedlot rations; several studies have demonstrated the use of up to $20 \%$ flaxseed in the diet without negatively affecting performance (9). Flaxseed has high levels of energy and protein and promotes feed intake and weight gain. Flaxseed has also been shown to offer additional benefits over its nutritional value alone, however flax is a highly palatable feed ingredient and contains high levels of nutrients (10). The previous studies have shown that Omega-3 source has affected some carcass characteristics, such as carcass weight, rib eye area, 12th rib fat thickness, muscle weight, fat distribution and carcass cuts. As well as, marbling scores, and quality grade have been affected by flaxseed supplementation for instant (11-13). Ground flaxseed increased marbling and grade scores when the finishing diet was supplemented with ground flaxseed (9). Flaxseed is the richest land-based source of the omega- 3 fatty acid $\alpha$ linolenic acid, or ALA (14). However, flaxseed is unique among oilseeds because of its exceptionally high content of ALA (18:3, n-3), contains 35 to $45 \%$ oil, of which 45 to $52 \%$ is ALA (15). The deposition and distribution of body fat observed in the study of (13) suggested that the polyunsaturated fatty acids from the fish oil could be a repartitioning factor for carcass fats in lambs and could have a favorable effect on the carcass fatness and the quality of lamb meat. These results indicate that the low level (3\%) of flaxseed powder is the best to improve and increase the efficiency of meat production and reduce the deposition of fat in the animal's body (16). Increasing levels $(0,5,10$, and $15 \%)$ of ground flaxseed in a swine diet for the final 25 days before slaughter increased the content of healthful omega-3 fatty acids in bacon and loin chops. The $15 \%$ flaxseed diet caused the greatest increase, but consumers were able to identify bacon from the higher levels in triangle tests. Thus, $15 \%$ dietary flaxseed is probably the highest level that should be used with finishing hogs (17). The $\alpha$-linolenic acid is the precursor of n-3 fatty acids de novo synthesis. The effect of the different forms of linseed supplementation in diet was analyzed in cattle (18-20), pigs (21), lambs $(22,23)$ and goat (24). 
Otherwise, (25) and (26) reported no differences for daily gain, age and live weight at slaughter between high and low forage diet fed to Friesian young bulls, moreover the oilseed supplementation (rapeseed and crushed linseed, respectively) did not have any effect on performance traits. The inclusion of linseed in maize silage diet did not influence the growth performance (27). Similarly, to (20) supplementing concentrate with or without linseed during the finishing period of grass fed steers the daily gain did not change significantly, and the different forage to concentrate ratios with/ without linseed supplementation did not significantly affect the performance and slaughter traits. The supplementation of flax seed to diets of finishing Hanwoo steers improved sensory evaluations which might have been caused by increases in flavor related amino acids such as methionine, glutamic acid and $\alpha$-AAA and peptides, anserine and carnosine, and their complex reactions (28). Maddock et al. (29) included that flaxseed in the diets of finishing beef heifers did not affect $(p=0.32)$ fat thickness over the 12th rib. These results might be caused by increases in the concentration of free amino acids, glutamic acid, methionine, and $\alpha-\mathrm{AAA}$, and peptides, anserine and carnosine, and their complex reactions. Some studies have shown that carcass traits under way to increase the concentration of unsaturated fatty acids (UFA) using vegetable or fish oil supplements in feeds and to reduce the level of cholesterol in animal products through appropriate nutrition: (30), eggs (31) and meat (32). Several feed strategies have been tested to increase the n-3 UFA content of lamb meat such as fish oil used in the past or more recently vegetable sources like linseed. Further detailed studies, however, to understand mechanisms for the improved beef flavors by feeding flax seed in the diet of finishing beef cattle are necessary. Therefore, the objective of this project is to investigate the effect of dietary supplementation of Ground Flaxseed on performance and carcass characteristics of Karadi male lambs.

\section{Materials and methods}

\section{Animals, experimental design, and diets}

This study was carried out at the animal production field, Department of Animal Science, College of Agricultural Science, University of Sulaimani, Bakrajo, Sulaimani, Iraq, over the periods of October 20th, 2014 to January 23th, 2015. Flaxseed was used in feeding period that lasted for 90 days using (12) twelve Karadi lambs with live body weight of $26 \pm 0.018$ and 6 months old, which divided into 3 equal groups (4 lambs/group). The ration was gradually offered to the lambs over a period of 2 weeks as adaptation period, at the same time, the lambs were drenched orally against internal worms, Ascarida, Lung and tape worms and repeated 14 days later using LevozaniDE. PROMECTINE is used also against external and internal parasites at the beginning of the experiment and 14 days later via subcutaneous of lambs. They were also vaccinated using COGIAVAX (Vaccine) polyvalent inactivated vaccine against Clostridial infections in ruminants, adjuvated with aluminum hydroxide gel which was used at the beginning of the experiment.

The lambs were randomly allocated into three treatments to receive either control ration no Ground flaxseed (GF) $0 \%$, or ration containing $4 \%$ Ground Flaxseed (T1), or diet containing 8\% Ground Flaxseed (T2). All the lambs were received an equal daily allowance of concentrate ration (3\% of the body weight). The formulations of the concentrate diet are presented in (Table 1). The lambs were randomly penned individually indoors on dry earth bedding and the concentrate was supplied once daily $(9: 00 \mathrm{am})$. The straw was given ad libitum. Each ration treatment was tested for 2 weeks adaptation and 8 weeks of feeding periods respectively. Daily feed intake and refused were measured and sampled for 8 weeks. The lambs were weighed once weekly from the beginning till the end of the experiment.

Table 1: Formulation and chemical composition of concentrate diets

\begin{tabular}{lccc}
\hline Ingredients (\%) & Control & T1 & T2 \\
\hline Barley & 41 & 37 & 33 \\
Wheat & 30 & 30 & 30 \\
Yellow Corn & 15 & 15 & 15 \\
Soybean meal & 12 & 12 & 12 \\
Flaxseed & 0 & 4 & 8 \\
Salt & 1 & 1 & 1 \\
Minerals and vitamins & 1 & 1 & 1 \\
\hline Chemical composition & & & \\
\hline Crude protein $(\mathrm{CP}) \%$ & 15.72 & 16.19 & 16.66 \\
Metabolizable energy & 12.47 & 12.42 & 12.37 \\
ME (MJ/Kg) * &
\end{tabular}

Calculated metabolize energy $\mathrm{ME}(\mathrm{MJ} / \mathrm{kg} \mathrm{DM})$ and $\mathrm{CP}$ representing two components of the feeds from the tables of chemical analysis of the Iraqi feed materials (33), except ME of Flaxseed calculated as stated by (9).

\section{Slaughtering and carcass characteristics}

At the end of the feeding trial ( 8 weeks), all lambs were slaughtered. The lambs were weighed immediately before slaughter to provide slaughter body weight (SBW). Slaughtering was performed according to the Islamic way by severing the jugular vessels, esophagus and trachea without stunning. The lambs were slaughtered in an experimental abattoir. In this method, the conscious animals were placed in lateral recumbence with head facing upwards. Bleeding was carried out by an incision on the jugular furrow at the occipito-atlantal junction close to 
head, severing both carotid arteries, jugular veins and in some cases the trachea, esophagus and spinal cord. Immediately after slaughter, the head was racked by hind legs and skinning was completed. Immediately after skinning evisceration was carried out and the carcass components were weighted. Then several quantity characteristics for carcasses were studied, which include: Hot carcass weight (HCW), Dressing percentage, Thickness of subcutaneous fat, Rib eye area, Partition and cutting of Carcass.

\section{Statistical analysis}

Data were analyzed by using XL Stat, version 7.5, 2004. (34). The following model was used:

$Y i j=\mu+T i+e i j$

Where:

$\mu=$ The overall means of traits,

$\mathrm{Ti}=$ The effect of treatments $(\mathrm{C}, \mathrm{T} 1$ and $\mathrm{T} 2)$,

eij= Random error, assumed to be equal to zero and variance is $62 \mathrm{e}(\mathrm{N} \sim 0,62 \mathrm{e})$.

The significant differences between means of traits included in this study were determined by using Duncan's multiple range tests under the probability $(\mathrm{P}<0.05)(35)$.

\section{Results and discussion}

The aim of the current study was to investigate the effect of dietary supplementation of Ground Flaxseed on performance and carcass characteristics of Karadi male lambs. All traits depend both on genetic and environmental factors. Heredity and environment interact to produce their effects. This means that the way genes act depends on the environment in which they act. In the same way, the effects of environment depend on the genes with which they work. We previously showed that inhibiting of myostatin gene caused a significant increase in muscle mass and reduction in fat depots with depression of adipogenesis (36). In the present study we studied the environmental effect which includes using flaxseed supplementation. The results in table 2 show the effect of GF feeding on final live body weight, hot carcass weight (HCW), Dressing percentages at slaughter body weight (SBW). The results indicated that no significant differences were found among treatments concerning these traits. It clarifies that there was mathematical decreased in final live body weight, hot carcass weight might be due to addition of ground flaxseed (GF). These results agree with those reported by (37) when lambs fed diet supplemented with linseed oil and mineral bioplex. Similar findings were observed by many other reports $(32,38,39)$.

Table 2: Effect of ground flaxseed supplementation on carcass measurement (Mean \pm Standard Deviation)

\begin{tabular}{lccc}
\hline Treatment & Final live body wt. $(\mathrm{kg})$ & Hot carcass wt. $(\mathrm{kg})$ & Dressing percentage $(\%)$ \\
\hline Control $(0 \%)$ & $26.850 \pm 1.909^{\mathrm{a}}$ & $13.190 \pm 2.234^{\mathrm{a}}$ & $49.01 \pm 3.426^{\mathrm{a}}$ \\
T1 $(4 \%)$ & $26.650 \pm 6.576^{\mathrm{a}}$ & $12.930 \pm 4.313^{\mathrm{a}}$ & $48.16 \pm 3.086^{\mathrm{a}}$ \\
T2 $(8 \%)$ & $26.200 \pm 3.960^{\mathrm{a}}$ & $11.830 \pm 1.286^{\mathrm{a}}$ & $44.73 \pm 1.780^{\mathrm{a}}$ \\
\hline
\end{tabular}

Means having different small letters among treatments (columns) for each trait are significantly different $(\mathrm{P}<0.01)$.

The effect of ground flaxseed GF supplementation on rib eye area and fat thickness which are presented in table 3. The results were significantly affected by GF Supplementation. The results also show that GF supplementation tended to increase the rib eye area. Highest value for this trait was achieved with $\mathrm{T}_{2}\left(14.145 \mathrm{~cm}^{2}\right)$ and the lowest value was $\left(10.005 \mathrm{~cm}^{2}\right)$ for $\mathrm{C}$ group. On the other hand, GF supplementation tended to decrease the fat thickness, the lowest value was observed in T2 $(2.375 \mathrm{~mm})$ and the highest value was observed in C group $(5.015 \mathrm{~mm})$. We previously could to decrease fat in this study; GF supplementation generally increased rib eye area, with decrease in fat thickness in $T_{1}$ and $T_{2}$ as compared with $C$ group. These findings agree with those results reported by (40) who found that different particle size of rapeseed and linseed supplementation in ration of lamb diets increased rib eye area, in contrast, (37) reported no significant differences between treatments in rib eye area. While (22) reported no-significant decrease in fat thickness. Also (1) observed that lambs fed fish meal diet had a smaller $(\mathrm{P}<0.05)$ fat depth compared with lambs fed fish oil with protected sunflower meal (FOSMP) diet.

Table 3: Effect of ground flaxseed supplementation on subfat thickness and rib eye area (Mean \pm Standard Deviation)

\begin{tabular}{lcc}
\hline Treatment & Sub-fat thickness $(\mathrm{mm})$ & Rib eye area $\left(\mathrm{cm}^{2}\right)$ \\
\hline Control $(0 \%)$ & $5.015 \pm 0.049^{\mathrm{a}}$ & $10.005 \pm 1.039^{\mathrm{A}}$ \\
T1 $(4 \%)$ & $3.695 \pm 0.629^{\mathrm{b}}$ & $12.035 \pm 0.205^{\mathrm{AB}}$ \\
T2 $(8 \%)$ & $2.375 \pm 0.191^{\mathrm{C}}$ & $14.145 \pm 0.955^{\mathrm{B}}$ \\
\hline
\end{tabular}

Means having different small letters among treatments (columns) for each trait are significantly different $(\mathrm{P}<0.01)$, Means having different capital letters among treatments (rows) for each trait are significantly different $(\mathrm{P}<0.05)$.

Table 4 clarifies the effect of GF supplementation on the major and secondary carcass cuts. From the results 
denoted that GF supplementation had no significant influence on the carcass cuts except breast and flank cuts which were significantly differed. The breast and flank cuts value showed irregular trend with GF supplementation. Baranowski et al. (37) reported that no significant differences were found among treatments in weight of leg and in leg tissues (meat, fat and bones) composition when fed the diet supplemented with linseed oil and mineralbioplex.

Baranowski et al. (37) reported that no significant changes were recorded with fish oil supplementation on the weights of the half carcass and the separate cuts, which tended to decrease in the animals from the experimental group. Similar trend was reported by (12) in cattle, but (41) observed higher weight of the carcass and the carcass cuts in kids in response to fish oil supplementation. The obtained results revealed significant and no significant differences in cut percentages which might be related to differences in growth patterns in the different locations of animal body, and this response may reflect changes in growth patterns. Further detailed studies, however, to understand mechanisms for the improved beef flavors by feeding flax seed in the diet of finishing beef cattle are necessary.

Table 4: Effect of ground flaxseed supplementation on the carcass cuts (Mean \pm Standard Deviation)

\begin{tabular}{lcccccccc}
\hline Treatment & Leg & Shoulder & Loin & Rack & Breast & Fore shank & Flank & Neck \\
\hline \multirow{2}{*}{ Control (0\%) } & $2091.107 \pm$ & $1361.607 \pm$ & $277.207 \pm$ & $620.757 \pm$ & $485.107 \pm$ & $242.607 \pm$ & $255.907 \pm$ & $135.707 \pm$ \\
& $261.417^{\mathrm{a}}$ & $410.617^{\mathrm{a}}$ & $59.609^{\mathrm{a}}$ & $37.901^{\mathrm{a}}$ & $48.295^{\mathrm{A}}$ & $25.951^{\mathrm{a}}$ & $47.164^{\mathrm{A}}$ & $10.819^{\mathrm{a}}$ \\
\multirow{2}{*}{ T1 (4\%) } & $2025.956 \pm$ & $1310.456 \pm$ & $456.556 \pm$ & $562.956 \pm$ & $494.556 \pm$ & $317.956 \pm$ & $262.306 \pm$ & $274.256 \pm$ \\
& $563.918^{\mathrm{a}}$ & $368.049^{\mathrm{a}}$ & $62.438^{\mathrm{a}}$ & $157.614^{\mathrm{a}}$ & $65.266^{\mathrm{AB}}$ & $49.143^{\mathrm{a}}$ & $23.759^{\mathrm{A}}$ & $26.658^{\mathrm{a}}$ \\
T2 (8\%) & $1268.625 \pm$ & $1358.625 \pm$ & $630.925 \pm$ & $430.475 \pm$ & $434.025 \pm$ & $457.625 \pm$ & $218.475 \pm$ & $421.225 \pm$ \\
& $1155.483^{\mathrm{a}}$ & $73.468^{\mathrm{a}}$ & $58.902^{\mathrm{a}}$ & $69.438^{\mathrm{a}}$ & $49.002^{\mathrm{B}}$ & $131.751^{\mathrm{a}}$ & $12.869^{\mathrm{B}}$ & $75.448^{\mathrm{a}}$ \\
\hline
\end{tabular}

Means having different small letters among treatments (columns) for each trait are significantly different $(\mathrm{P}<0.01)$, Means having different capital letters among treatments (rows) for each trait are significantly different $(\mathrm{P}<0.05)$.

\section{Conclusion}

In conclusion, the results of the present study suggest that dietary supplementation with different levels of Ground Flaxseed resulted in significant $(\mathrm{P}<0.05)$ improvements in rib eye area, significant decrease $(\mathrm{P}<0.01)$ in sub-fat thickness, the results for the carcass cuts showed significant decrease $(\mathrm{P}<0.05)$ for each of Flank and Breast. These increases in rib eye area may be reflecting the increase in weight of loin cut. However, the decrease in fat thickness may be reflecting the decrease in fat percentages in the carcass that indicates the effect of Ground Flaxseed in improvement of carcass traits.

\section{Acknowledgment}

The authors are sincerely thankful for the animal farm research station at the College of Agricultural Sciences / University of Sulaimani at Bakrajo for the financial and technical support for this research project.

\section{References}

1. Ponnampalam EN, Trout GR, Sinclair AJ, Egan AR, Leury BJ. Comparison of the color stability and lipid-oxidative stability of fresh and vacuum packaged lamb muscle containing elevated omega-3 and omega-6 fatty acid levels from dietary manipulation Meat Sci. 2001;58:151-161.

2. Williams CM. Dietary fatty acids and human health. Annal Zootech. 2000;49:165-180.
3. Oprzadek J, Oprzadek A. Modyfikowanie skladu kwasow tluszczowych w tluszczu miesa przezuwaczy. Medycyna Weterynaryjna, 2003;59(6):492-495.

4. Barowicz T. Witamina E w zywieniuzwierzat. Przeglad Hodowlany. Sci. 2000; 7: 61-79.

5. BeMiller JN, Whistler RL, Barkalow DG, Chen CC. Aloea, chia, flax seed, okra, psyllium seed, quince seed, and tamarin gums. In: Industrial Gums. Whistler RL, BeMiller JN editors. New York: Academic Press; 1993. 227-256 p.

6. Anonymous. Flax seed oil-facts and information. Symmetry. 2002;800-231-7277.

7. Daun J, Barthet V, Chornick T, Duguid S. Structure, composition, and variety development of flaxseed. In: Thompson L, Cunanne S. editors. Flaxseed in Human Nutrition. Champaign: Illinois State Press; 2003. $1-40 \mathrm{p}$.

8. Oomah B. Processing of flaxseed fiber, oil, protein, and lignan. In: Thompson L, Cunanne S. editors. Flaxseed in Human Nutrition. Champaign: Illinois State Press; 2003. 363- 386 p.

9. Newkirk DR. Flax Feed Industry Guide. Canada Flax. 2015;1-5.

10. Drouillard JS, Good EJ, Gordon CM, Kessen TJ, Sulpizio MJ, Montgomery SP, Sindt JJ. Flaxseed and flaxseed products for cattle: Effect on health, growth performance, carcass quality and sensory attributes. Proc. 59 ${ }^{\text {th }}$ Flax Institute, N.D.; 2002. 72-87 p.

11. Ponnampalam, EN, Sinclair AJ, Egan AR, Blakeley SJ, Li D, Leury BJ. Effect of dietary modification of muscle long-chain n-3 fatty acid on plasma insulin and lipid metabolites, carcass traits, and fat deposition in lambs. J Anim Sci 2001;79:895- 903.

12. Wistuba TJ, Kegley EB, Apple JK. Influence of fish oil in finishing diets on growth performance, carcass characteristics and sensory evaluation of cattle. J Anim Sci 2006;84:902-909.

13. Marinova P, Popova T, Banskalieva V, Raicheva E, Ignatova M, Vasileva V. Effect of fish oil supplemented diet on the performance, carcass composition and quality in lambs. Bulgarian J Agri Sci. 2007;13:729-737.

14. Connor WE. Alpha-linolenic acid in health and disease. Anim J Clin Nutr. 1999;69:827-828. 
15. Bhatty RS. Nutritional composition of whole flaxseed and flaxseed meal. In: Flaxseed in Human Nutrition. Ed. S. C. Cunnane and L. H. Thompson. AOCS Press, Champaign, IL. 1995. 22-45 p.

16. Al-Rubeii AM, Zahir HG. effect of different levels of flaxseed powder as a source of omega-3 on the weight muscles and fat distribution for carcasses of karadi lambs. J Anim Sci. 2014;LVII:74-81.

17. Romans JR, Johnson RC, Wulf DM, Libal GW, Costello WJ. Effects of ground flaxseed in swine diets on pig performance and on physical and sensory characteristics and omega-3 fatty acid content of pork. $\mathrm{J}$ Anim Sci. 1995;73:1982-1986.

18. Raes K, De Smet S, Balcaen A, Claeys E, Demeyer D. Effect of linseed feeding at similar linoleic acid levels on the fatty acid composition of double-muscled Belgian Blue young bulls. Meat Sci. 2004;66:307-315.

19. Nuernberg K, Dannenberger D, Nuernberg G, Ender K, Voigt J, Scollan ND, Wood JD, Nute GR, Richardson RI. Effect of a grassbased and a concentrate feeding system on meat quality characteristics and fatty acid composition of longissimus muscle in different cattle breeds. Liv Prod Sci. 2005;94:137-147.

20. Razminowicz, RH, Kreuzer M. Leuenberger H, Scheeder MRL. Efficiency of extruded linseed for the finishing of grass-fed steers to counteract a decline of omega-3 fatty acids in the beef. Livest Sci. 2008;114:150-163.

21. Nuernberg K, Fischer K, Nuernberg G, Kuechenmeister U, Klosowska D, Eliminowska-Wenda G, Fiedler I, Ender K. Effects of dietary olive and linseed oil on lipid composition, meat quality, sensory characteristics and muscle structure in pigs. Meat Sci. 2005;70:63-74.

22. Borys T, Borys A, Gasior R. Effect of feeding rapeseed and linseed diets and their supplementation with vitamin $\mathrm{E}$ on health quality of lamb meat. Arch Tierz. 2004;47:189-197.

23. Gruszecki T, Junkuszew A, Lipiec A, Lipecka C, Szymanowska A, Patkowski K, Szymanowski M. Composition of fatty acids of muscle tissue of lambs fed feedstuff supplemented with flax seeds. Arch Tierz. 2006;49:181-185.

24. Pieniak-Lendzion K, Niedziółka R, Borkowska T, Horoszewicz E. Effect of linseeds supplement in mixtures on chemical composition and fatty acids profile in male kids. Arch Tierz. 2006;49:244-248.

25. Kreuzer M, Gerhardy H, Ossowski D, Voss GEM. Improved storage and dietetic properties of carcass fat tissues in growing Holstein as well as Charolais $\times$ Holstein bulls fed full-fat rapeseed. Arch Tierz. 1995;38:163-175.

26. Aharoni Y, Orlov A, Brosh A. Effects of high-forage content and oilseed supplementation of fattening diets on conjugated linoleic acid (CLA) and trans-fatty acids profile of beef lipid fractions. Anim Feed Sci Technol. 2004;117:43-60.

27. Bartoň L, Marounek M, Kudrna V, Bureš D, Zahrádková R. Growth performance and fatty acid profiles of intramuscular and subcutaneous fat from Limousin and Charolais heifers fed extruded linseed. Meat Sci. 2007;76:517-523

28. Choi CB, Kwon H, Kim SI, Yang UM, Lee JH, Park EK. Effects of rice bran, flax seed, and sunflower seed on growth performance, carcass characteristics, fatty acid composition, free amino acid and peptide contents, and sensory evaluations of native Korean cattle (Hanwoo). Asian Australas J Anim Sci. 2016;29(2):195-203.

29. Maddock TD, Bauer ML, Koch KB, Anderson VL, Maddock RJ, Barceló-Coblijn G, Murphy EJ, Lardy GP. Effect of processing flax in beef feedlot diets on performance, carcass characteristics, and trained sensory panel ratings. J Anim Sci. 2006;84:1544-1551.

30. Micek P, Borowiec F, Marciński M, Barteczko J, Zając T. Wpływ dawek pokarmowych $\mathrm{z}$ udziałem nasion lnu na skład kwasów tłuszczowych i zawartość cholesterolu w mięsie i mleku owiec. Roś Ol. 2004;25:573-579.

31. Sosin, E, Borowiec F, Strzetelski, J, Smulikowska S. The effect of feeding regulator low $\alpha$-linolenic acid linseed on the fatty acid composition of egg yolks. J Anim Feed Sci. 2006;15:641-650.

32. Borowiec F, Micek P, Marciński M, Barteczko J, Zając T. Linseedbased diet for sheep. 2. Performance and chemical composition of meat and liver. J Anim Feed Sci. 2004;13(2):19-22.

33. Al-Khawaja AK, Matti SA, Asadi RF, Mokhtar KM, Aboona SH. The composition and nutritive value of Iraqi feedstuffs, Division Publication, Ministry of Agriculture, Iraq. 1978.

34. Addinsoft. XLSTAT Pro version 7.5.3 available at http://www.xlstat.com/en/home. 2005

35. Duncan DB. Multiple Ranges and Multiple F-tests. Biomet. 1955;11:1-42.

36. Yousif, AN. Myostatin and inhibition by its propeptide in pregnancy and old ages [dissertation]. Hawaii: University of Hawaii at Manoa;2013. 136 p.

37. Baranowski A, Gabryszuk M, Jozwik A, Bernatowicz E, Chylinski W. Fattening performance, slaughter indicators and meat chemical composition in lambs fed the diet supplemented with linseed and mineral bioplex. Anim Sci Papers Rep. 2007;25:35-44

38. Czauderna M, Kowalczyk J, Niedźwiedzka KM, Wą- sowska I, Pająk JJ. The effect of selenium and linseed oil on growth of sheep and content of selected fatty acids in m. longissimus dorsi. J Anim Feed Sci. 2004; 13:303-306.

39. Borys B, Jarzynowska A. Effects of vitamin E supplemented to rapeseed and linseed diets on the slaughter value of lambs. J Anim Feed Sci. 2005;14(1):227-230.

40. Borys B, Borys A. Effect of the form of rapeseed and linseed in lamb diets on some health quality parameters of meat. Annal Anim Sci. 2005;5(1):159-169.

41. Marinova P, Banskalieva V, Tzvetkova V. Body and carcass composition, and meat quality of kids fed fish oil supplemented diet. Opt Mediterraneennes. 2005;67:151-156. 